\title{
ASPEK PERLINDUNGAN KONSUMEN TERHADAP IKLAN PENGOBATAN ALTERNATIF DAN TRADISIONAL ${ }^{*}$
}

\author{
Indra Rahmatullah ${ }^{1}$ \\ Permalink: https://www.academia.edu/9997449
}

\begin{abstract}
Aspects of Consumers Protection toward Alternative and Traditional Medical Advertisement. Intellectual Property Rights (IPR) is one of the main factors for economic growth of one country. Basically, IPR is an exclusive right given by a country to creators, inventors or designers for their inventions. On its development, IPR aims not only to give legal protection from the third party but also to earn money or economic benefits by several ways; IPR can be sold, licensed, and as a collateral to get loan from the banks. Those happen because of the inability to value the real assets of IPR with IPR valuation.
\end{abstract}

Key words: IPR, collateral, and Valuation

\begin{abstract}
Abstrak: Aspek Perlindungan Konsumen Terhadap Iklan Pengobatan Alternatif dan Tradisional. Hak Kekayaan Intelekatual (HKI) telah terbukti merupakan salah satu hal yang utama bagi pertumbuhan ekonomi di suatu negara. Pada dasarnya HKI merupakan hak eksklusif yang diberikan negara kepada pencipta, penemu atau pendesain untuk hasil kreasi atau penemuannya. Seiring dengan perkembangan HKI di belahan dunia, HKI bukan lagi hanya bertujuan untuk memberikan perlindungan hukum saja dari pihak ketiga, tetapi juga aset HKI dapat menghasilkan uang atau keuntungan ekonomi melalui beberapa cara yaitu HKI dapat dijual, dilisensikan, termasuk dapat digunakan sebagai jaminan (collateral) untuk mendapatkan pinjaman di bank. Hal itu terjadi, mengingat belum adanya pengalaman dan kemampuan dalam menilai berapa nilai aset riil HKI dengan cara valuasi (valuation) HKI.
\end{abstract}

Kata Kunci: HKI, Collateral (jaminan), dan Valuasi

${ }^{*}$ Diterima tanggal naskah diterima: 20 Juni 2014, direvisi: 25 Agustus 2014, disetujui untuk terbit: 10 November 2014.

${ }^{1}$ Fakultas Syariah dan Hukum UIN Jakarta. Jl. Ir. H. Juanda No. 95 Ciputat. E-mail: indra.r86@gmail.com. 


\section{Pendahuluan}

Kebutuhan akan kesehatan merupakan hak asasi setiap warga negara. Tak pelak masyarakat dari golongan apapun baik dari strata kelas atas sampai bawah membutuhkan pelayanan kesehatan yang memadai. Tak jarang dan segan pula untuk mendapatkan pelayanan kesehatan yang bagus, bagi masyarakat yang mempunyai penghasilan tinggi rela untuk membayar mahal pelayanan kesehatan di rumah sakit yang bonafide. Akan tetapi, lain halnya dengan golongan tidak mampu, bagi mereka dengan penghasilan rendah, jikalau tidak bisa mendapatkan pelayanan kesehatan di rumah sakit yang bonafide, memilih untuk mendapatkan pelayanan kesehatan yang disediakan oleh pemerintah secara gratis seperti di Rumah Sakit Umum Daerah (RSUD).

Jikalau tidak, mereka dapat menggunakan pengobatan alternatif atau pengobatan tradisional. Alasannya sangat sederhana, selain harga pelayanan kesehatan yang terjangkau oleh masyarakat berpenghasilan rendah, juga dikarenakan dipercayai obat yang diberikan ampuh untuk penyakit yang dideritanya meskipun tidak menutup kemungkinan masyarakat kelas atas yang memilih pengobatan alternatif dan tradisional juga sehingga jumlahnya cukup besar masyarakat Indonesia yang menggunakan jasa tersebut.

Potensi besar tersebut, memunculkan banyak praktik pengobatan alternatif dan tradisional yang menawarkan berbagai macam layanan penyembuhan penyakit sehingga menimbulkan persaingan antara beberapa pelaku usaha pengobatan tersebut. Untuk memudahkan dalam mempromosikan pelayanan kesehatan yang diberikan, pelaku pengobatan memasarkan jasa kesehatannya dengan berbagai cara, baik brosur, spanduk maupun melalui iklan di media televisi.

Pemasaran atau promosi yang dilakukan oleh pelaku usaha pengobatan tradisional atau alternatif sedang gencar dan marak dilakukan di media televisi. Salah satunya adalah Fenomena Tong Fang sebagai salah satu klinik Traditional Chinese Medicine (TCM). Akan tetapi, karena ditengarai melanggar ketentuan periklanan, Komisi Penyiaran Indonesia (KPI) menegur melalui nomor surat 336/K/KPI/05/12 tertanggal 31 Mei 2012 yang isinya mengimbau kepada seluruh stasiun Televisi untuk menghentikan iklan Tong Fang tersebut. Alasannya, iklan tersebut menayangkan testimonial pasien dan pemberian diskon bila pasien melakukan pengobatan di klinik tersebut. ${ }^{2}$

Upaya promosi pengobatan alternatif dan tradisional yang dilakukan oleh pelaku usaha melalui media termasuk salah satunya dengan media seperti televisi dan brosur atau selebaran menimbulkan berbagai pelanggaran etika periklanan dan hak-hak konsumen (pasien) yang harus dilindungi. Perilaku tersebut merupakan dampak dari persaingan pengobatan alternatif dan tradisional yang tidak sehat.

Apabila pengobatan alternatif dan tradisional dilarang dengan ketentuan persyaratan-persyaratan peraturan perundang-undangan yang berlaku,

2 "Imbauan Iklan "Klinik Tong Fang" Seluruh Stasiun TV, Komisi Penyiaran Indonesia”, http://www.kpi.go.id/component/content/article/12-umum/30564-imbauan-iklanqklinik-tong-fangq-seluruh-stasiun-tv. 08 Januari 2013. 
permasalahan yang timbul adalah berpotensi dapat menghilangkan subtansi dari tujuan pengobatan alternatif daripada pengobatan konvensional yang sudah dijalani pasien. Prinsip dasar pengobatan alternatif dan tradisional merupakan solusi lain yang ditawarkan dan yang dapat pasien pilih apabila pengobatan konvensional tidak memberikan kesembuhan.

Umumnya, pengobatan alternatif dan tradisional dipromosikan dengan menggunakan bujukan yang memberi kesan kesembuhan dan keampuhan (mujarab) daripada pengobatan konvensional. Prinsip dasar tersebut tentu bertentangan dengan beberapa ketentuan peraturan yang mengatur periklanan di bidang kesehatan yang tidak boleh memberikan kesan kesembuhan.

\section{Iklan Sebagai Media Promosi Pengobatan Tradisional}

Pengobatan tradisional diatur dalam Undang-undang No. 36 tahun 2009 tentang Kesehatan pada pasal 1 angka 16 yaitu "Pelayanan kesehatan tradisional adalah pengobatan dan/atau perawatan dengan cara dan obat yang mengacu pada pengalaman dan keterampilan turun temurun secara empiris yang dapat dipertanggungjawabkan dan diterapkan sesuai dengan norma yang berlaku di masyarakat".

Untuk jenis pelayanan kesehatan tradisional diatur dalam pasal 59 ayat 1 yaitu: a). Pelayanan kesehatan tradisional yang menggunakan keterampilan; dan b). Pelayanan kesehatan tradisional yang menggunakan ramuan.

Sebelum Undang-undang Kesehatan mengalami perubahan pada tahun 2009, pengaturan pengobatan tradisional sudah ada melalui Keputusan Menteri Kesehatan Republik Indonesia Nomor 1076/Menkes/SK/VII/2003 Tentang Penyelenggaraan Pengobatan Tradisional Pasal 1 angka 1 menerangkan bahwa "Pengobatan tradisional adalah pengobatan dan/atau perawatan dengan cara, obat dan pengobatnya yang mengacu kepada pengalaman, keterampilan turun temurun, dan/atau pendidikan/pelatihan, dan diterapkan sesuai dengan norma yang berlaku dalam masyarakat".

Sedangkan dasar hukum pengobatan alternatif adalah Peraturan Menteri Kesehatan RI No: 1109/Menkes/Per/IX/2007 tentang Penyelenggaraan Pengobatan Komplementer-Alternatif di Fasilitas Pelayanan Kesehatan pada pasal 1 angka 1 bahwa: "Pengobatan komplementer-alternatif adalah pengobatan non konvensional yang ditujukan untuk meningkatkan derajat kesehatan masyarakat meliputi upaya promotif, preventif, kuratif, dan rehabilitatif yang diperoleh melalui pendidikan terstruktur dengan kualitas, keamanan, dan efektifitas yang tinggi yang berlandaskan ilmu pengetahuan biomedik, yang belum diterima dalam kedokteran konvensional."3

Pengobatan tradisional yang dimaksud di atas menggunakan berbagai media untuk mengiklankan jasanya. Iklan menurut Belch (Belch dan Belach 1998) adalah media atau piranti yang paling penting sebagai alat promosi bagi perusahaan yang ingin meraih konsumen secara massal. Karena iklan

${ }^{3}$ Lebih jelas lihat Peraturan Menteri Kesehatan RI No: 1109/Menkes/Per/IX/2007 tentang Penyelenggaraan Pengobatan Komplementer-Alternatif Di Fasilitas Pelayanan Kesehatan 
menjangkau secara massal dalam waktu yang relatif bersamaan, maka informasi yang digunakan dalam iklan dapat diandalkan untuk membujuk sekaligus menciptakan citra (positif) dari suatu produk dengan hasil akhir dari bujukan tersebut konsumen mengambil keputusan untuk membeli produk. ${ }^{4}$

Jones (Wells, Burnet dan Moriarty 1998) mengemukakan bahwa iklan dapat efektif dalam mempengaruhi dan membujuk konsumen harus mempunyai tiga kualitas: (1) iklan harus cukup atraktif (menarik perhatian) dilihat oleh konsumen, (2) mengambil bentuk secara visual dan (3) tidak cukup sekedar mempengaruhi tetapi harus digambarkan secara samar atau tidak jelas (fuzzy imagery). ${ }^{5}$

Menurut Peraturan Menteri Kesehatan Republik Indonesia Nomor 1787/Menkes/Per/IIX/2010 tentang Iklan dan Publikasi Pelayanan Kesehatan menerangkan bahwa yang dimaksud iklan adalah adalah informasi yang bersifat komersial dan layanan rnasyarakat tentang tersedianya jasa, barang, dan gagasan yeng dapat dimanfaatkan oleh khalayak dengan atau tanpa imbalan kepeda lembaga penyiaran yang bersangkutan. ${ }^{6}$

Iklan yang bertujuan untuk mempromosikan pelayanan kesehatan diatur dalam Pasal 1 angka 1 yang menyebutkan bahwa "Iklan pelayanan kesehatan adalah kegiatan komunikasi persuasif atau pengenalan/promosi tentang kebijakan, program, dan/ pelayanan kesehatan dalam bentuk gambar, suara, dan/ tulisan dengan tujuan menarik minat dan memudahkan masyarakat".

Pada Pasal 6 tepatnya huruf (e) dan (n) ditentukan aturan periklanan untuk promosi kesehatan, yaitu: memuji diri secara berlebihan, termasuk pernyataan yang bersifat superlatif dan menyiratkan kata "satu-satunya' atau yang bermakna mengenai keunggulan, keunikan atau kecanggihan sehingga canderung bersifat menyesatkan dan memberikan testimoni dari bekas pasiennya yang diterbitkan dalam media massa.

Undang-undang No. 8 tahun 1999 tentang Perlindungan Konsumen tidak memberikan definisi tentang iklan, akan tetapi menjelaskan tentang Promosi yang pengertiannya berdekatan dengan iklan. Dalam pasal 1 angka 6 disebutkan bahwa "Promosi adalah kegiatan pengenalan atau penyebarluasan informasi suatu barang dan/ jasa untuk menarik minat beli konsumen terhadap barang dan/jasa yang akan dan sedang diperdagangkan.

\section{Kritik Terhadap Peraturan Menteri Kesehatan (Permenkes Nomor 1787/Menkes/Per/IDX/2010) Pasal 6 huruf (e) dan (n)}

Penulis berpendapat bahwa ketentuan Peraturan Menteri Kesehatan Pasal 6 huruf (e) dan (n) tersebut tidak secara serta merta dan otomatis dapat diperlakukan kepada jenis promosi pengobatan tradisional dan alternatif. Letak

\footnotetext{
${ }^{4}$ Yakub Adi Kristanto, "Iklan dan Konsumen dalam Perspektif Pemasaran dan Hukum (Analisis Iklan yang Menyesatkan menurut Undang-undang Perlindungan Konsumen)", Jurnal Studi Pembangunan Interdisipliner, Vol. XIX No. 3, Kritis, 2007, hlm. 197, diunduh dari http://isjd.pdii.lipi.go.id/admin/jurnal/19307189204.pdf, 10 Januari 2012.

${ }_{6}^{5}$ Ibid., hal. 198.

6 Pasal 1 angka 3 Peraturan Menteri Kesehatan Republik Indonesia Nomor 1787/Menkes/Per/IIX/20l0 tentang Iklan dan publikasi pelayanan kesehatan
} 
permasalahannya ada dua, yaitu dari segi redaksi muatan iklan promosi dan segi sosiologis-antropologis.

Pertama, dari segi redaksi muatan iklan promosi sangat sulit kiranya menerapkan sanksi Permenkes ini kepada promosi pengobatan tradisional dan alternatif. Sifat dan karakteristik pengobatan alternatif dan tradisional adalah sebagai jalan lain yang dipilih oleh pasien terhadap penyembuhan penyakit yang dideritanya. Dengan membawa karakter "alternatif" dan "tradisional", mau tidak mau penyedia jasa kesehatan alternatif dan tradisional menggunakan katakata yang menjanjikan kesembuhan kepada pasiennya dan memuat testimoni dalam iklannya. Hal demikian sebagai konsekuensi dari kata alternatif dan tradisional tersebut.

Dari iklan brosur Wen Chi Fung (Modern Traditional Medicine) misalnya ada unsur "iklan yang mengesankan kesembuhan" dan adanya "testimoni". Unsur yang mengesankan kesembuhan terdapat dalam kalimat: "Penyembuhan segala macam penyakit luar dalam". "Pastikan penyakit kronis anda sembuh tuntas. Ribuan pasien yang sudah divonis tidak bisa sembuh, Insya Allah dapat tertolong sembuh dengan sempurna”.

Sedangkan unsur testimoni disampaikan dalam brosur tersebut oleh 5 orang pasien yaitu Ny. Mourin, Bapak Acep, Ny. Tonah, Bapak Herman Susanto dan Ny. Malinda. Kesemuanya memberikan testimoni kesembuhan penyakitnya setelah berobat di klinik Wen Chi Fung.

Dua contoh di atas menggambarkan bahwa Pasal 6 huruf (e) dan (6) Permenkes Nomor 1787/Menkes/Per/IIX/2010 terhadap Iklan yang mengesankan kesembuhan kiranya sangat sulit untuk diterapkan pada promosi pengobatan alternatif dan tradisional meskipun media yang dipakai oleh kedua klinik (Tong Fang dan Wen Chi Fung) berbeda. Batasan terhadap tidak diperbolehkan mengesankan keampuhan dan pemberian testimoni sulit dihindari karena sifat dan karakeristik yang melekat pada pengobatan alternatif dan tradisional tersebut.

Logika sederhana yang muncul kemudian adalah bahwa jikalau dalam promosi tidak mengesankan suatu hal yang memberikan rangsangan psikologis kepada pasien berupa kesembuhan dan kemanjuran, ini tidak ada bedanya dengan pengobatan konvensional atau pengobatan dengan ilmu kedokteran pada umumnya.

Kedua. Di sisi sosiologis-antropologis. Image pengobatan tradisional dan alternatif yang menawarkan keampuhan masih menjadi idola di kalangan masyarakat Di Indonesia faktanya kepercayaan masyarakat kepada berbagai tahayul dan cara-cara pengobatan yang berbau mistik sangat kentara yang tidak memandang status apakah orang awam, rakyat jelata ataupun para pejabat. Hal tersebut terkait dengan beberapa lapisan dan jenis masyarakat di Indonesia. ${ }^{7}$

\footnotetext{
${ }^{7}$ Soerjono Soekanto membagi tipe-tipe masyarakat sebagai berikut:

1. Masyarakat dengan struktur sosial dengan kebudayaan bersahaja dengan ciri-ciri sebagai berikut:

a. Hubungan atas dasar hubungan dara atau faktor kekerabatan maupun dasar tempat tinggal sangat kuat
} 
Sehingga, ibarat hukum ekonomi, jika permintaan naik maka hargapun naik, dengan begitu pengobatan tradisional dan alternatif yang menawarkan kesembuhan dibarengi dengan testimoni tumbuh subur di Indonesia. Adi Susilo TF (seorang dokter) mengatakan bahwa:

Bagi masyarakat sebenarnya tidak diperhatikan, apakah ilmu kedokteran atau yang lain. Yang penting penyakitnya sembuh, keluhan hilang, apalagi dengan biaya ringan. Falsafah ilmu pengetahuan menyatakan, bahwa ilmu pengetahuan merupakan salah satu kebenaran, tapi bukan satu-satunya kebenaran. Ada kebenaran yang lain. Analoginya, ilmu kedokteran adalah kebenaran, dalam cara penyembuhan tapi toh bukan satu-satunya kebenaran. Ada cara-cara lain yang tidak atau belum terjangkau oleh ilmu kedokteran yang juga merupakan kebenaran. ${ }^{8}$

Hal ini membuktikan bahwa cara pengobatan tradisional dan alternatif semacam itu masih sangat diperlukan dalam membantu pelayanan kesehatan masyarakat, khususnya bagi masyarakat yang masih belum terjangkau layanan

b. Organisasi atau kelompok sosial pada pokoknya didasarkan pada adat istiadat yang terbentuk melalui tradisi

c. Kepercayaan yang sangat kuat pada tenaga-tenaga gaibyang dianggap sangat mempengaruhi kehidupan manusia, akan tetapi yang tidak mampu dikuasai oleh manusia.

d. Keterampilan diwariskan secara turun temurun.

e. Tingkat buta huruf yang relatif tinggi.

f. Hukum yang berlaku adalah hukum adat.

g. Pekerjaan sosial maupun ekonomis dilakukan secara gotong royong.

2. Masyarakat dengan struktur sosial dan kebudayaan madya dengan ciri-ciri sebagai berikut:

a. Hubungan antara faktor kekerabatan tetap kuat; hubungan kesatuan tempat tinggal mengendor.

b. Adat istiadat masih tetap dihormati, akan tetapi masyarakat sudah mulai terbuka terhadap pengaruh-pengaruh luar.

c. Kepercayaan akan kekuatan-kekuatan gaib timbul apabila orang tidak dapat mengatasi masalah yang dihadapinya dengan mempergunakan rasio.

d. Lembaga-lembaga pendidikan sudah semakin banyak.

e. Tuingkat buta huruf menurun

f. Hukum tertulis mulai mendampingi hukum adat (hukum tidak tertulis).

g. Produksi mulai tertuju pada pasaran yang luas lingkupnya.

3. Masyarakat dengan struktur dan kebudayaan modern dengan ciri-ciri sebagai berikut:

a. Hubungan antar manusia lebih didasarkan pada keserasian kepentingan pribadi dan masyarakat.

b. Hubungan dengan masyarakat lain dilakukan secara terbuka.

c. Kepercayaan kuat pada manfaat ilmu dan teknologi dalam peningkatan kesejahteraan.

d. Penggolongan atas dasar profesi, dan kesempatan kerja yang professional.

e. Pendidikan tinggi formal merata.

f. Hukum tertulis berlaku secara umum; berlakunya hukum adat didasarkan pada hukum tertulis.

g. Kesadaran politik yang relative merata.

Soerjono Soekanto, Bunga Rampai Hukum dan Profesi Kedokteran dalam Masyarakat Indonesia, ed. Jef Leibo, (Yogyakarta: Liberty, Cet. Pertama, 1986), hlm. 80.

${ }^{8}$ Ibid., hlm. 80. 
kesehatan dari Pemerintah. Faktanya, diakui juga oleh dr. Iman Hilman yang mengatakan bahwa:

\begin{abstract}
"Kalau memang ada cara dukun yang mampu menghilangkan penyakit atau penderitaan, kami kira dunia kedokteran cukup berlapang dada untuk menerima cara tersebut baik untuk keperluan diagnostik ataupun terapi. Sebagai bukti bahwa dunia kedokteran cukup berlapang dada dalam menerima cara-cara tradisional, telah banyak dibuktikan; misalnya akupuntur, penggunaan hipnotisme dalam bidang psikiatri, penggunaan obat-obat jamu dan sebagainya. Namun meskipun demikian, harus diuji dahulu keampuhannya sebelum diterapkan kepada manusia."
\end{abstract}

Undang-undang No. 8 Tahun 1999 tentang Perlindungan Konsumen sangat mewanti-wanti hak-hak konsumen yang harus dijamin dan tidak boleh dilanggar oleh pelaku usaha. Pasal 17 menyebutkan bahwa pelaku usaha dilarang memproduksi iklan yang:

a. mengelabui konsumen mengenai kualitas, kuantitas, bahan, kegunaan dan harga barang dan/atau tarif jasa serta ketepatan waktu penerimaan barang dan/atau jasa;

b. mengelabui jaminan/garansi terhadap barang dan/atau jasa;

c. memuat informasi yang keliru, salah, atau tidak tepat mengenai barang dan/atau jasa;

d. tidak memuat informasi mengenai risiko pemakaian barang dan/atau jasa;

e. mengeksploitasi kejadian dan/atau seseorang tanpa seizin yang berwenang atau persetujuan yang bersangkutan;

f. melanggar etika dan/atau ketentuan peraturan perundang-undangan mengenai periklanan.

Dengan demikian, Peraturan Menteri Kesehatan (Permenkes) Nomor 1787 Tahun 2010 yang mengatur tentang iklan dan publikasi pelayanan kesehatan dan jenis iklan yang dianggap mengesankan kesembuhan pada Pasal 6 huruf (e) dan (n) tidak dapat diterapkan atau tidak operasional secara sosiologis terhadap jenis pengobatan alternatif dan tradisional.

Di sisi lain, Undang-undang No. 12 tahun 2011 tentang Pembentukan Peraturan Perundang-undangan, dalam pasal 6 huruf "d" menyebutkan bahwa sebuah aturan harus dapat dilaksanakan. Dilaksanakan berarti bahwa setiap pembentukan peraturan perundang-undangan harus memperhitungkan efektivitas peraturan perundang-undangan tersebut di dalam masyarakat, baik secara filosofis, sosiologis, maupun yuridis.

Penulis tetap setuju bahwa tetap diperlukan sebuah aturan tentang iklan pengobatan, tetapi harus ada suatu pengecualian ketentuan yang mengatur

9 Ibid. Dengan dua alasan di atas, yakni alasan redaksi muatan bahasa iklan dan sosiologis-antropologis, Peraturan Menteri Kesehatan (Permenkes) Nomor 1787 Tahun 2010 yang mengatur tentang iklan dan publikasi pelayanan kesehatan dan jenis iklan yang dianggap mengesankan kesembuhan (Mock-Up Advertisement) Pasal 6 huruf (e) dan (n) tidak dapat diterapkan atau tidak operasional secara sosiologis terhadap jenis pengobatan alternatif dan tradisional, hlm. 73 . 
promosi dalam jenis pengobatan alternatif dan tradisional. Ini sesuai dengan pendapat Mr. Inge Van Der Vlies dalam bukunya Hand Boek Wetgeving (1987) yang mengkonsepsikan bahwa dalam pembentukan peraturan perundang-undangan hendaknya memperlakukan situasi atau keadaan tertentu (Het beginsel van de individuale rechts bedeling). ${ }^{10}$

\section{Penutup}

Bahwa seharusnya ada pengecualian terhadap berbagai peraturan yang mengatur tata cara promosi iklan bagi jenis promosi pengobatan tradisional dan alternatif. Sifat dan karakteristik yang khas melekat pada jenis pelayanan kesehatan tersebut tidak sama baik secara karakter aslinya maupun redaksi kalimat dalam penggunaan iklannya bila dibandingkan dengan pengobatan konvensional. Hal demikian merupakan fakta yang ada di tengah-tengah masyarakat baik dari segi sosiologis maupun antropologis masyarakat Indonesia.

\section{Pustaka Acuan}

A.B Wiranata, I Gede, Dasar-Dasar dan Moralitas (Pengantar Kajian Etika Profesi Hukum), (Bandung: Citra Adity Bakti, 2005)

Adi Kristanto, Yakub, Iklan dan Konsumen dalam Perspektif Pemasaran dan Hukum (Analisis Iklan yang Menyesatkan menurut Undang-undang Perlindungan Konsumen), Kritis, Jurnal Studi Pembangunan Interdisipliner Vol. XIX No. 3, 2007, diunduh dari http://isjd.pdii.lipi.go.id/admin/jurnal/19307189204.pdf, 10 Januari 2012.

Badrulzaman, Meriam Darus, "Perlindungan Terhadap Konsumen Dilihat dari Sudut Perjanjian Baku", dimuat dalam Hasil Simposium Aspek-Aspek Hukum Masalah Perlindungan Konsumen yang diselenggarakan oleh Badan Pembinaan Hukum Nasional, Bina Cipta, Jakarta, tahun 1986. Darmodihardjo, Darji dan Shidarta, Pokok-Pokok Filsafat Hukum, (Jakarta: Gramedia Pustaka Utama, 1995, Cet. Ke I.

${ }^{10}$ Ditinjau dari segi yuridis-formil dan pedoman teknik pembentukan peraturan perundang-undangan, menurut salah seorang pakar perundang-undangan, Mr. Inge Van Der Vlies dalam bukunya Hand Boek Wetgeving (1987), menyebutkan beberapa asas yang baik dalam pembentukan peraturan perundang-undangan, yaitu: Het beginsel van dedulijk doelsstelling (kejelasan tujuan pembentukan), Het beginsel van het jiuste orgaan (penentu kewenangan lembaga/orang yang berhak membentuk dan menerima delegasi pembentukan), Het nood zakelijk heids beginsel (keperluan mendesak), Het beginsel van devoerbaarheid (kemungkinan pelaksanaan peraturan yang dibentuk), Het beginsel van de consensus (konsensus atau kesepakatan antara pemerintah dan rakyat), Het beginsel van de duidelijk terminologie en duidelijk systematijk (peristilahan dan sitematika yang jelas), Het beginsel van de kenbaarjeid (asas dapat diketauhi dan dikenali oleh setiap orang), Het rechtgelijk heids beginsel (perlakuan yang sama terhadap hukum), Het beginsel van de individuale rechts bedeling (perlakuan khusus terhadap keadaan tertentu). Marulak Pardede, Dis-sinkronisasi Peraturan Perundang-undangan dalam Pperpajakan pada Penagihan Pajak dengan Surat Paksa, Jurnal Legislasi Indonesia, Vol. 3 No. 2 , Juni, Direktorat Jenderal Peraturan Perundang-undangan Republik Indonesia, 2006 , hal. 111. 
Dewan Periklanan Indonesia, Etika Pariwara Indonesia (Tata Krama dan Tata Cara Perikalanan Indonesia), Cetakan ketiga, September 2007.

Gendo, Udayana, Teori Dasar Kedokteran Cina, (Yogyakarta: Kanisius:, 2006), , Integrasi Kedokteran Barat dan Kedokteran Cina, (Yogyakarta: Kanisius, 2006).

J.L.K, Valerina, Modul Metode Penelitian Hukum, (rev. ed., Jakarta: Fakultas Hukum Universitas Indonesia, 2009).

Kansil, CST. dan Christine ST. Kansil, Pokok-Pokok Etika Profesi Hukum Bagi Mahasiswa dan Subjek Hukum; Etika Profesi Hukum: Hakim, Jaksa, Penasihat Hukum, Notaris, Jaksa, dan Polisi, (Jakarta: Pradnya Paramitha, 2005, Cet. Ke-2).

Nasution, Az, Hukum Perlindungan Konsumen Suatu Pengantar, (Jakarta: Diadit Media, 2002, Cetakan Kedua).

Laporan Tim Pengkajian Hukum tentang Aspek Hukum dan Etika Bisnis Periklanan di Indonesia, (Jakarta: BPHN, 1994).

Pardede, Marulak, Dis-sinkronisasi Peraturan Perundang-undangan dalam Pperpajakan pada Penagihan Pajak dengan Surat Paksa, Jurnal Legislasi Indonesia, Vol. 3 No. 2 , Juni, Direktorat Jenderal Peraturan Perundang-undangan Republik Indonesia, 2006.

Pusat Bahasa Departemen Pendidikan Nasional, Kamus Besar Bahasa Indonesia, (Jakarta: Balai Pustaka, 2005, Cet. Ketiga).

Samsul, Inosentius, Silabus Perkuliahan Hukum Perlindungan Konsumen Program Magister Hukum Universitas Pancasila, 2012

Soemitro, Ronny Hanitijo, Metodologi Penelitian Hukum, (Jakarta: Ghalia Indonesia, 1983).

Soekanto, Soerjono Pengantar Penelitian Hukum, (Jakarta: Universitas Indonesia, 1986).

Shofie, Yusuf Perlindungan Konsumen dan Instrumen-Instrumen Hukumnya, (Bandung: PT. Citra Aditya Bakti, 2005, Edisi Revisi Cetakan Kedua).

Perundang-undangan

Peraturan Menteri Kesehatan RI No: 1109/Menkes/Per/IX/2007 tentang Penyelenggaraan Pengobatan Komplementer-Alternatif Di Fasilitas Pelayanan Kesehatan.

Peraturan Menteri Kesehatan Republik Indonesia Nomor 1787/Menkes/Per/IIX/2010 tentang Iklan dan Publikasi Pelayanan Kesehatan.

Undang-undang Penyiaran Nomor 32 Tahun 2002 tentang Penyiaran. Undang-undang Nomor. 8 tahun 1999 tentang Perlindungan Konsumen Surat Imbauan Komisi Penyiaran Indonesia (KPI) No. 336/K/KPI/05/12 tertanggal 31 Mei 2012.

\section{Internet}

"Seberapa

Besar

Manfaat

Pengobatan

Alternatif?", http://www.gizikia.depkes.go.id/archives/5485. 08 Januari 2013. 
204- Indra Rahmatullah; Aspek Perlindungan Konsumen

Metro, "Iklan Klinik Tong Fang Langgar Etika Pariwara Tidak boleh ada promosi dalam iklan pelayanan kesehatan", http://metro.news.viva.co.id/news/read/344559-iklan-klinik-tong-fang-langgaretika-pariwara, 10 Januari 20 